\title{
JAGODA BUDZIK
}

ORCID: 0000-0002-6287-8340

Katedra Judaistyki im. Tadeusza Taubego, Uniwersytet Wrocławski

\section{„Mi-Szoa li-tkuma” Polska jako antynomia Izraela}

Podczas oficjalnych obchodów izraelskiego Dnia Niepodległości (Jom ha-Acmaut), 18 kwietnia 2018 roku, w trakcie próby generalnej przed uroczystością na Górze Herzla, kiedy na scenie symbolicznie przedstawiano najistotniejsze wydarzenia $\mathrm{z}$ narodowej historii, minister kultury i sportu Miri Regew nie spodobało się wymienienie wśród nich Zagłady na równorzędnej pozycji jednego ze zdarzeń w łańcuchu dziejów. Na jej prośbę do fragmentu poświęconego Holokaustowi dołączono elementy takie jak pojawiający się w tle odgłos jadącego pociągu czy wejście na scenę dźwigających walizki dzieci z przyszytymi do ubrań żółtymi gwiazdami Dawida. Tę zmianę w scenariuszu Miri Regew skomentowała słowami: „Jestem bardzo zadowolona $\mathrm{z}$ tego, jak udało nam się podkręcić Zagładę"1. Sytuacja ta skupia - jak soczewka - elementy stanowiące punkt wyjścia do rozważań o funkcjach pełnionych przez Polskę w opowieściach o pielgrzymkach do miejsc pamięci Szoa. Wspomniane zdarzenie czyni to już na poziomie miejsca, w którym się rozegrało. Cmentarz wojskowy zlokalizowany jest na Górze Herzla, która wznosi się ponad Instytutem Jad Waszem i daje przestrzenny wyraz odbywanej przez naród żydowski drodze "mi-Szoa li-tkuma”, czyli „od Zagłady do odrodzenia” (to określenie jest stałym elementem izraelskiej narracji tożsamościowej). Niefortunnie sformułowany przez polityczkę

\footnotetext{
${ }^{1}$ I. Szatran: Hiclachnu lefaceach et ha-Szo'a: Regew horta lehosif kolot rakewet we-newichot le-tekes ha-mesu'ot. Dostępne w Internecie: https://www.haaretz.co.il/news/politi/1.6009376 [data dostępu: 17.04.2018]. Jeżeli nie zaznaczono inaczej, wszystkie przekłady tekstów obcojęzycznych pochodzą od autorki artykułu. W oryginalnej wypowiedzi Miri Regew używa hebrajskiego wyrazu לפצח, który dosłownie oznacza „rozłupywać” lub „rozkruszać”. W tym kontekście miał on opisać zabieg znaczącego podkreślenia obecności Szoa w szeregu historycznych wydarzeń, o których była mowa podczas ceremonii.
} 
i wprowadzony w życie zamiar „podkręcenia Zagłady” uwydatnia natomiast jej rolę $\mathrm{w}$ opowieści o powstawaniu państwa i wskazuje na istotne miejsce, które zajmuje ona wśród jego symbolicznych fundamentów.

\section{Dychotomiczne opowiadanie izraelskiej historii Pielgrzymki}

W ten sposób konstruowana dychotomia kategorii „Zagłada” i „odrodzenie" przenoszona jest $\mathrm{w}$ kształtowanej instytucjonalnie zbiorowej wyobraźni również na obszar narodowy i geograficzny, stawiający w opozycji odpowiednio Żydów i gojów, a także Polskę - kraj Holokaustu, i Izrael - kraj żydowskiego odrodzenia. Ten ostatni układ, jego dosłownie przestrzenny wymiar, być może najpełniej obrazuje jedną z wielu funkcji, które Zagłada pełni w konstruowanej dziś oficjalnie izraelskiej narracji tożsamościowej, przetwarzanej, odtwarzanej i dekonstruowanej przez kulturę. Jej stała obecność wskazuje na stopień, w jakim pamięć o Szoa uczestniczy w opisywaniu wydarzeń z historii państwa, i na to, jak bezpośrednio łączy się ją $\mathrm{z}$ faktem jego powstania. W artykule zamierzam przyjrzeć się miejscu i zadaniom - takim, jakimi przedstawiają je członkowie trzeciego pokolenia po Zagładzie - które izraelski dyskurs narodowy wyznaczył w tym układzie Polsce. Pielgrzymki do miejsc pamięci Szoa, na których się skupię, nie są oczywiście jedynym funkcjonującym na dość szeroką skalę typem izraelskich podróży do Polski. Obok nich wymienić można masowe pielgrzymki chasydów na groby cadyków oraz turystykę rekreacyjną, jednak nie angażują one w sposób tak dosłowny izraelskiego kontekstu narodowego. Perspektywa pielgrzymek do miejsc pamięci jest więc szczególnie symptomatyczna, opozycja między Polską a Izraelem od samego początku stanowiła bowiem w przypadku trzeciego pokolenia stały element oficjalnej edukacji o Zagładzie ${ }^{2}$.

Wspomniana zależność wyznaczająca miejsce Polski w izraelskim zagładowym imaginarium, szczególnie zaś jej przestrzenny charakter, wyraźnie uwidacznia się w najpowszechniejszym u przedstawicieli trzeciego pokolenia typie doświadczenia „kraju tam”. Odbywane przez izraelską młodzież pielgrzymki do miejsc pamięci Zagłady, choć coraz częściej obejmują nie tylko Polskę, lecz także Czechy, Niemcy, Litwę i Ukrainę, nawet w takim wypadku zwyczajowo i skrótowo określa się jako „masa’ot le-Polin” („podróże do Polski”)

2 J. Chaitin, T. Litvack-Hirsch: The Shoah Runs Through Our Veins. The Relevance of the Holocaust for Jewish-Israeli Young Adults. "Idea" 2015, Vol. 14, no 1. Dostępne w Internecie: http:// www.ideajournal.com/articles.php?id=49 [data dostępu: 20.04.2018].

${ }^{3}$ Por. J. Feldman: Above The Death Pits, Beneath the Flag. Youth Voyages to Poland and the Performance of Israeli National Identity. New York 2008; J. Chaitin, T. Litvack-Hirsch: The 
w odniesieniu do nich termin „pielgrzymki” zaproponowany został przez antropologa Jackiego Feldmana, który stwierdza:

Gdy już zdecydowałem, że tego rodzaju podróż najlepiej będzie postrzegać jako rytuał, pojawiło się pytanie: jakiego rodzaju rytuał dokładnie? Kontekst grupowej podróży, quasi-religijny język często używany do opisu tego doświadczenia oraz waga symbolicznych odwołań i ceremonii sugerują, że pielgrzymka stanowi tu najbliższą analogię. Fakt, że taki termin opisujący podróże jest dla większości wychowawców niewygodny, wiele mówi o pozycji ich samych wobec rytuału. [...] Innymi słowy, łatwiej im zaakceptować praktykę pielgrzymek jako część programu, który promują, niż uznać ten rytuał za to, czym w istocie jest ${ }^{4}$.

Feldman dodaje, że nadawane podróżom struktura i cele noszą wyraźne znamiona rytuału - w tym wypadku mającego na celu przeprowadzenie uczestników przez kolejne etapy Zagłady, a następnie umożliwienie powrotu do Izraela z nowo nabytą tożsamością ocaleńca i wyższą świadomością wagi wynikającej z faktu posiadania przez naród żydowski własnego państwa ${ }^{5}$. W wyniku tak zacieśniającego się splotu łączącego z założeniem państwa drogę do ocalenia (w całości pokonywaną jedynie przez nielicznych) zbiorowa izraelska tożsamość przyjmuje rolę tego, kto ową drogę pokonał, a w związku z tym - kogo prawo do istnienia nie może zostać ponownie zakwestionowane i którego działania zmierzające do przetrwania mogą być legitymizowane a priori. Polska, jako centralna przestrzeń wydarzeń Szoa, w tym kontekście stała się rodzajem naturalnego odnośnika, ogólnie przyjętego mechanizmu, każącego wiązać pamięć o Holokauście z obszarem konkretnego państwa, a zatem niejako w jego granicach skupiać zbiorowe doświadczenie pamięci o Zagładzie.

Kwestią, która w istotny sposób wpływa na ostateczny kształt tego przestrzennego odniesienia, jest polityczny i ideologiczny wymiar pielgrzymek. W odwołujących się do nich narracjach Polska pełni zwykle funkcję antynomii Izraela, mającej niejako dodatkowo potwierdzać konieczność istnienia żydowskiego państwa, a więc także jego obrony przed wciąż aktualnym zagrożeniem ${ }^{6}$. Przywoływana już wcześniej fraza „mi-Szoa li-tkuma” dość dobrze obrazuje ten układ, znajdujący odzwierciedlenie również w tekstach stanowiących przedmiot niniejszych rozważań. Rozmaitość ich proweniencji, a zatem wielość języków i poetyk, przy użyciu których trzecie pokolenie opowiada o doświadczeniu pielgrzymki, nie pozostawia wątpliwości co do stopnia zakorzenienia wspomnianej zależności w zbiorowej świadomości reprezentantów tej generacji.

Shoah Runs...; A. Ben-Amos, T. Hoffman: Banu leszachrer et Majdanek. Masa'ot Cahal le-Polin we-gijus zikaron ha-Szo'a. "Israeli Sociology" 2011, Vol. 2, s. 331-354.

${ }^{4}$ J. Feldman: Above The Death..., s. 4.

5 Tamże, s. 6-7.

${ }^{6}$ Zob. I. Zertal: Naród i śmierć. Zagłada w dyskursie i polityce Izraela. Przeł. J.M. KŁoCZowsKi. Kraków 2010. 
O ile sam instytucjonalnie narzucony mechanizm łączenia podróży do Polski z ideologicznymi i politycznymi uwarunkowaniami panującymi dziś w Izraelu staje się problemem coraz częściej poddawanym krytyce (czego przykład można

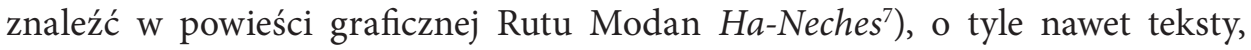
w których same pielgrzymki pojawiają się jako przykład instrumentalizowania przez instytucjonalny dyskurs zagładowej pamięci, w dalszym ciągu często korzystają z modelu dychotomii Polska - Izrael, kraj śmierci - kraj życia itd. Niekiedy jest to kwestia nawyku myślowego, czasami - sposób budowania struktury dramatycznej, innym razem zabieg ten ma natomiast charakter subwersywny.

\section{Okres błękitny \\ Rola pielgrzymek do Polski w okresie dojrzewania}

Powszechny charakter szkolnych pielgrzymek, a przede wszystkim moment, w którym młodzi ludzie na nie wyruszają, czyni z przyswajania tego szczególnego rozumienia Polski integralną część procesu dojrzewania. Sposób, w jaki Polska zostaje wpisana w cykl inicjacyjnych doświadczeń, również opiera się na dychotomicznym podziale: między Izraelem, czyli przestrzenią skupiającą znajome i powszechnie przyjmowane normy, składające się na bezpieczne status quo, a „krajem tam” - niemalże eksterytorialną, na poły fantazmatyczną przestrzenią, kumulującą zarówno wyblakłe klisze, jak i silne, odczuwane zbiorowo emocje, skłonną pomieścić to, na co nie ma miejsca $\mathrm{w}$ domowym systemie symbolicznym. Podział ten warunkowany jest różnymi intencjami twórców, przynależnością gatunkową ich tekstów i dyktowanymi przez nią celami. W każdym z przypadków jednakże powodem wprzężenia w opowieść motywu Polski i wiążących się z nią skojarzeń jest rozpatrywana na różnych poziomach radykalna symboliczna jej odmienność od ojczyzny bohaterów.

Powieść Jinona Nira Ha-Tkufa ha-kchula („Okres błękitny”) to klasyczny przykład młodzieżowej powieści inicjacyjnej. W izraelskim wariancie historia o młodzieńczym buncie, pierwszym zakochaniu i autonomicznie podejmowanych decyzjach w nieunikniony sposób zawiera także doświadczenie odbywanej zwykle w klasie jud-bet ${ }^{9}$ wyprawie do Polski. W owym ujęciu kraj ten staje się przestrzenią inicjacji - pierwszego dla wielu młodych ludzi wyjazdu za granicę oraz intensywniej przeżywanych miłości (głównym dylematem bohatera pod-

\footnotetext{
7 Wydanie polskie: R. Modan: Zaduszki. Przeł. Z. Solakiewicz. Warszawa 2013.

${ }^{8}$ J. Nir: Ha-Tkufa ha-kchula. Tel Awiw 2001.

${ }^{9}$ W izraelskim systemie szkolnictwa w ten sposób oznacza się klasę dwunastą - ostatnią klasę liceum.
} 
czas podróży jest to, jak zostać sam na sam w pokoju z koleżanką z klasy $\left.{ }^{10}\right)$. Dziewczęta są natomiast wyjątkowo podekscytowane perspektywą wizyty w warszawskich centrach handlowych - to ze względu na nią, jako że stanowić ma nagrodę za dobre sprawowanie, domagają się od chłopców, by zachowywali się przyzwoicie podczas zwiedzania Muzeum na Majdanku ${ }^{11}$. Wątek pamięci o Zagładzie - w założeniu centralny przecież element wyjazdu - ustępuje tu miejsca doświadczeniom młodości, nie jest jednak doświadczeniem samym w sobie. Słowa „Zagłada” i „Polska” podlegają zatem desemantyzacji - stają się oznaczeniem stałego etapu w życiu młodego człowieka, a zarazem one same jedynie częściowo decydują o jego kształcie.

Podobnego procesu można dopatrywać się w innej powieści młodzieżowej: Lechacot et ha-okijanus („Przemierzyć ocean”) Zehawit Tal-On ${ }^{12}$. W tym przypadku wątek pamięci o Zagładzie stanowi znacznie istotniejszy element akcji. Bohaterka książki, Neti, udaje się w szkolną podróż do Polski z poczuciem metafizycznego posłannictwa - głęboko wierzy, że konfrontacja z polskimi miejscami pamięci o Szoa zbliży ją do zmarłego pradziadka, który z niej ocalał ${ }^{13}$. $\mathrm{Na}$ miejscu dziewczyna poznaje tajemniczego młodzieńca, Erika, w którym się zakochuje. Kulminacja melodramatycznego wątku przychodzi w chwili, gdy Neti dowiaduje się, że jej ukochany jest Niemcem, co więcej - potomkiem nazistó $w^{14}$. Na tym jednak nie kończą się genealogiczne zagadki skrywane przez jego przodków. Podczas odwiedzin w domu młodzieńca Neti poznaje matkę chłopaka, która - jak wyznaje jej w tajemnicy - jest Żydówką. Powodem jej rozstania z mężem, ojcem Erika, były zaś nazistowskie tradycje pielęgnowane $\mathrm{w}$ jego rodzinie i sprzeciw wobec jego małżeństwa z Żydówką ${ }^{15}$. Ten fragment historii prowadzi do dwóch wniosków istotnych dla zrozumienia przekazu powieści. Po pierwsze, miłość Erika i Neti nie jest tak niemożliwa i zakazana, jak można było sądzić na początku - obydwoje są według Halachy Żydami. Po drugie, okoliczności rozstania rodziców chłopaka stanowią jasny sygnał, że niebezpieczeństwo grożące Żydom ze strony nazistów nie minęło wraz z końcem Zagłady, ale przechodzi z pokolenia na pokolenie. Erika od podzielenia losu męskich przodków uchroniła prawdopodobnie żydowska matka. Polska jako tło początkowej części tej historii wzmaga konstytuujące ją napięcie, a tego rodzaju splot narodowych kategorii okazuje się dla młodych odbiorców bardzo latwym do odczytania kodem. Istotne jest także geograficzne ulokowanie przez Tal-On poszczególnych zdarzeń. O ile Neti i Erik spotykają się w Polsce, gdzie zakochują się w sobie i gdzie ich miłość przechodzi pierwszą poważną próbę,

\footnotetext{
${ }^{10}$ J. Nir: Ha-Tkufa..., s. 66.

${ }_{11}$ Tamże, s. 65.

12 Z. TAL-ON: Lechacot et ha-okijanus. Lod 2015.

13 Tamże, s. 19.

14 Tamże, s. 100.

15 Tamże, s. 151-152.
} 
o tyle ich stopniowe, wzajemne odkrywanie tożsamości odbywa się już w Izraelu i w Stanach Zjednoczonych. Ich ponowne spotkanie, ukoronowane wieńczącym melodramatyczny wątek zdaniem: „Siłą naszej miłości zwyciężymy wszystko”, to już wydarzenie umiejscowione w Nowym Jorku - dość odległym od Polski, by młodzieńcza miłość wyzwoliła się z kształtujących historyczną narrację schematów. Bohaterom łatwiej jest przemierzyć tytułowy ocean niż przekroczyć ramy narzucane przez konstruowaną wokół Polski narrację.

Taki status pielgrzymek do Polski i różnorakie role, które odgrywają one w procesie dojrzewania, nie są jednak jedynymi czynnikami, za sprawą których polskie przestrzenie $\mathrm{i}$ ich przeszłość aktywnie uczestniczą $\mathrm{w}$ opowiadaniu izraelskiej teraźniejszości.

\section{Polska opowiada izraelską teraźniejszość}

Lea Tokajer, uczestniczka jednej z wielu odbywających się w latach 90 . pielgrzymek, wśród swoich zapisków z tamtego okresu - opublikowanych w wydanym po wyprawie, zbiorowym tomie dokumentującym podróż - pozostawiła kilka wierszy stanowiących zapis jej doświadczenia i odtwarzających wskazaną opozycję pomiędzy obszarem życia i śmierci. W tekście Lihijot be-Polin („Być w Polsce") autorka opisuje, jak postpamięciowo odtwarzany lęk towarzyszący jej konfrontacji z historią Zagłady i miejscem, w którym się dokonywała, przezwyciężony zostaje poczuciem siły wynikającym z narodowej przynależności: „A ja kroczę po zbrukanej polskiej ziemi / idę wśród chwały i dumnie / myśląc o cudownym narodzie do którego należę / i o Państwie"16. Opozycja ta zostaje rozwinięta w utworze Boker riszon be-Israel le-achar ha-mas'a le-Polin („Pierwszy poranek w Izraelu po podróży do Polski”), którego sam tytuł sugeruje już dystans między autorką a opisywaną przestrzenią. Dystans ów uwydatnia się na kolejnych poziomach: „Tam, w zimnej Polsce, nie widziałam motyli / Ostatni motyl Polskę opuścił"17, następnie zaś tak zarysowany obraz przeciwstawiony zostaje wizji bezpiecznego i szczęśliwego Państwa Izrael, które w przeciwieństwie do Polski, lokującej się w obszarze przeszłości, należy już do porządku przyszłości ${ }^{18}$.

${ }^{16}$ L. Tokajer: Lihijot be-Polin. W: Dor le-dor jawi'a omer lizkor we-lo liszkoach. Red. E. Hartman. Aszkelon 2005, s. 390.

${ }^{17}$ L. TokAJER: Boker riszon be-Israel le-achar ha-mas'a le-Polin. W: Dor le-dor..., s. 395-396.

18 Tamże, s. 396. 


\section{Od nazistowskiej bestii do potwora pamięci}

Również polityczny wymiar i konsekwencje wycieczek - wątki stale obecne $\mathrm{w}$ debacie publicznej - znalazły wyraz w literaturze. Iszaj Sarid w wydanej w lipcu 2017 roku minipowieści Miflecet ha-zikaron („Potwór pamięci”) próbuje dokonać literackiej syntezy tego, jak izraelska polityka pamięci o Zagładzie nie tylko wpłynęła na myślenie o zbiorowej tożsamości, ale też jak zaprojektowała w całości zbiorową wyobraźnię. Utwór ma formę listu pisanego do dyrektora Jad Waszem przez głównego bohatera - izraelskiego historyka, przewodnika izraelskich wycieczek po miejscach pamięci, który w przygotowywanym doktoracie porównuje metody masowego mordowania w poszczególnych obozach.

Mężczyzna podejmuje się z ramienia Jad Waszem pracy przewodnika szkolnych grup po byłych miejscach pamięci z powodów pragmatycznych: gdzie indziej w Izraelu historyk może zarobić tyle pieniędzy? - pyta retorycznie. Od tego momentu jego życie toczy się na dwóch odrębnych płaszczyznach - w Izraelu, gdzie zostawił swoje życie rodzinne u boku żony i dziecka, oraz w Polsce, gdzie spędza większą część roku, zarabiając na ich utrzymanie, i gdzie obserwuje na bieżąco, jak izraelska polityka pamięci wpływa na przybywającą tu młodzież, ale też - na niego samego. $Z$ wiedzy historyka i jego autorytetu korzystają zresztą nie tylko licealiści. Z perspektywy zadań powierzanych bohaterowi w miarę upływu akcji Sarid stara się bowiem skonstruować znacznie szerszy obraz aktualnej kondycji pamięci o Zagładzie i jej zasięgu - ze wskazówek mężczyzny korzysta izraelski minister edukacji, który pospiesznie wpada do Auschwitz, by na tle baraków zrobić sobie do gazety pamiątkowe zdjęcie w kipie na głowie, izraelska armia, która poszukuje efektywnych metod wyburzania palestyńskich wiosek, archeolodzy prowadzący wykopaliska na terenie byłego obozu w Sobiborze czy ekipa filmowa.

Wyłaniająca się z opisów głównego bohatera Polska jest naznaczona Zagładą w niemal każdym obszarze toczącego się tu siedemdziesiąt lat po wojnie życia: według jego słów Polacy rodzą mniej dzieci, ponieważ nie ma już Żydów, przed którymi musiano by się demograficznie bronić, polskie lasy do dziś kryją w sobie krzyki tych, których tam mordowano, a na polskich drogach trwale odcisnął się ślad transportów. Mężczyzna ocenia zarazem, że taki jego odbiór polskich przestrzeni jest efektem działania tytułowego „potwora pamięci”, napędzającego machinę wycieczek oraz zbiorowego upamiętniania Zagłady w Izraelu, i próbuje się mu przeciwstawić. „Potwór pamięci” przywodzi na myśl skojarzenia z "nazistowską bestią”, którą w Patrz pod: Miłość Dawida Grossmana usiłował wyhodować mały Momik ${ }^{19}$. W jednej ze scen bohater Sarida tak objaśnia sens swojej pracy kilkuletniemu synowi:

${ }^{19}$ D. Grossman: Patrz pod: Miłość. Przeł. M. Sommer. Warszawa 2008. 
Wytłumaczyłem mu, że muszę wrócić do swojej pracy za granicą, że czekają tam na mnie. „Co to za praca, tato?” - zapytał. „Opowiada ludziom o tym, co się wydarzyło”, pomogła mi Rut. „A co się wydarzyło?” - Ido wbił we mnie zaniepokojony wzrok. „Był tam taki potwór, który zabijał ludzi” - powiedziałem. „I ty z nim walczysz?” - podekscytował się. „On już nie żyje” - próbowałem mu wytłumaczyć - „to potwór pamięci” ${ }^{20}$.

Tym razem jednak miejscem, w którym bestia w pełni przystępuje do działania, nie jest Izrael, a Polska - to tutaj właśnie, nie w Izraelu, młodzi ludzie (a wraz z nimi sam bohater) nabywają pragnienia siły i odrazy do fizycznej słabości. W jednej ze scen Sarid opisuje następujące zdarzenie: „Z jakiegoś powodu właśnie na Majdanku, na kilkuset metrach drogi z komór gazowych do pomnika prochów i palenisk, usłyszałem, jak mówią o Arabach, jak owinięci w izraelskie flagi szepczą, Arabowie, tak trzeba z nimi zrobić"21.

Umiejscowienie „potwora pamięci” - jak określa go bohater - w polskich przestrzeniach nie tylko potęguje opozycję między Polską a Izraelem, lecz także po raz wtóry wyraźnie zarysowuje granicę między emocjami przynależnymi każdej z przestrzeni. Nawet jeśli któraś z opozycji zostaje zachwiana, szybko okazuje się, że to zachwianie jedynie pozorne. W jednej ze scen bohater odwiedza Muzeum Auschwitz wraz z grupą uczniów jesziwy:

Po zakończonej wizycie w Auschwitz, przy wyjściu z obozu, zaczęli wymachiwać izraelskimi flagami, z entuzjazmem śpiewać Am Israel Chaj, i wykonywać żywiołowy taniec z ubranym zwojem Tory, który po kolei obejmując, przekazywali sobie z rąk do rąk. Kiedy na chwilę przerwali, podszedłem do dyrektora szkoły i szepnąłem: „W tym miejscu spoczywa nasz naród, nie wypada tu tańczyć".

Odpowiedział: „Ale my i nasza Tora żyjemy, wróciliśmy do naszego kraju. To dlatego tańczymy, w imię łaski, którą wyświadczył nam Pan. Koniec końców zwyciężyliśmy. Kochany, możesz kłócić się ze mną do jutra, to nic nie pomoże. W to wierzymy. Nie ma tu miejsca na smutek. Jesteśmy nadzieją i przyszłością. Chodź i zatańcz z nami”22.

Przesunięcie w dychotomicznym rozdziale pojęć i emocji okazuje się złudne. $\mathrm{W}$ istocie bohaterowie sceny, wraz ze swoim tańcem, pochodzą z porządku izraelskiego $\mathrm{i}$ to on kształtuje ich doświadczenie przestrzeni, a ich taniec na obciążonym żałobą terenie Polski wynika wyłącznie z faktu, że nie muszą się $\mathrm{z}$ nią identyfikować.

Umiejscowiony w Polsce izraelski rytuał przejścia jawi się zatem w omówionych tu tekstach jako jeszcze bardziej wielowymiarowy niż ten, o którym

\footnotetext{
${ }^{20}$ I. SARID: Miflecet ha-zikaron. Tel Awiw 2017, s. 61.

${ }^{21}$ Tamże, s. 17.

${ }^{22}$ Tamże, s. 55-56.
} 
pisze Feldman. Motyw Polski staje się w nich nie tylko narzędziem militarnego dyskursu, dodatkowym uzasadnieniem konieczności służby wojskowej lub potwierdzeniem bezwzględnej potrzeby istnienia żydowskiego państwa jako jedynego możliwego rozwiązania. Zyskuje on wymiar znacznie bardziej uniwersalny. W fantazmatycznej przestrzeni Polski dzieje się wszystko to, co nie miałoby prawa zdarzyć się - a w każdym razie nie z taką intensywnością - w nadającej kształt rzeczywistości, domowej przestrzeni bohaterów, lub to, co groziłoby zachwianiem konstytuującej ją narodowej struktury. Proces ten zauważalny jest zresztą nie tylko na poziomie geograficznych granic obydwu krajów. Chana Nawe w jednym z rozdziałów swojej pracy Nos'im we-nos'ot..., poświęconej podróżom w hebrajskiej literaturze współczesnej, przygląda się izraelskim wycieczkom do Polski, które, jak słusznie zauważa, stały się już trwale ugruntowanym motywem w wyobraźni zbiorowej, jak również w wyobraźni literackiej. Autorka doprecyzowuje, że chodzi tu zarówno o Polskę, jak i „Polskę - obejmującą także Niemcy i resztę Europy"23. W ten sposób wybrane przez nią teksty lokują swoją akcję w dwóch typach przestrzeni: Polsce rozumianej fizycznie i geograficznie oraz „Polsce” jako przestrzeni mityczno-fantazmatycznej, kumulującej te części narodowego imaginarium, które nie pasują do przyjętego na poziomie oficjalnej narracji sposobu postrzegania państwa.

Wśród analizowanych tam utworów (obok między innymi kanonicznych dla tematu, powstałych nieco wcześniej Lejad kfarim szketim („Nieopodal cichych wsi") Jehudit Hendel i powieści Rut Almog) autorka umieszcza opowiadanie Etgara Kereta Buty. Pochodzący z tomu Rury tekst najlepiej skądinąd rozpoznawalnego w Polsce hebrajskiego pisarza jest historią chłopca, który wraz ze swoją klasą w Dzień Pamięci Zagłady i Bohaterstwa udaje się do mieszczącego się w Jerozolimie Domu Pamięci Żydów z Wołynia. Tam, opacznie interpretując słowa przewodnika, uznaje wyprodukowane $w$ Niemczech adidasy za środek kontaktu ze zmarłym w Zagładzie dziadkiem ${ }^{24}$. Żaden $\mathrm{z}$ bohaterów utworu nie udaje się zatem w podróż do Polski w rozumieniu dosłownym, a jednak badaczka twierdzi, że do podróży tej mimo wszystko dochodzi. Że Dom Pamięci Żydów z Wołynia i podobne mu miejsca (wśród których Nawe wymienia między innymi muzeum Jad Waszem) to $\mathrm{w}$ istocie eksterytorialne przestrzenie, funkcjonujące niejako poza izraelskim porządkiem. Autorka pisze:

I tak uczniowie opuszczają bezpieczną przestrzeń murów izraelskiej szkoły i wraz z pełną zaangażowania nauczycielką udają się spełnić w Dzień Zagłady swój narzucony przez oficjalny program nauczania obowiązek. Jadą autobusem, oddalają się od domu w kierunku innej dzielnicy - „Polski”, to znaczy

${ }^{23}$ Ch. NAwE: Nos'im we-nos'ot. Sipurej masa ba-sifrut ha-iwrit he-chadasza. Jeruszalajim 2002, s. 275.

${ }^{24}$ E. Keret: Buty. W: Tenże: Tęskniąc za Kissingerem. Przeł. A. Maciejowska. Warszawa 2008, s. 98-101. 
do Domu Pamięci Żydów z Wołynia, Domu Pamięci Żydów Besarabii, Jad Waszem lub Domu Pamięci Bojowników Gett. To są właśnie małe polskie obszary leżące na naszej ziemi, z punktu widzenia fundamentalnie rozumianej izraelskości - obszary eksterytorialne. Istnieją w takim wymiarze i na takich zasadach, jakie wyznaczają im kolejne Dni Pamięci ${ }^{25}$.

Kumulując to, co bolesne, i to, czemu żydowskie społeczeństwo Izraela winno się sprzeciwiać, nie powinny i nie mogą one wchodzić w skład domowej (i zarazem narodowej) przestrzeni. W tej perspektywie izraelskie miejsca pamięci Zagłady są fantazmatycznymi namiastkami Polski, Polską w mniejszych dawkach, gotową do natychmiastowego podania, pozwalającą w razie potrzeby szybko przypomnieć o konieczności poświęcania się dla zbudowanego z trudem Państwa, okupionego milionami ofiar. Równocześnie jednoznaczne identyfikowanie tych przestrzeni z Polską pozwala zachować wyraźnie zewnętrzny charakter doświadczenia Zagłady.

\section{Co pomiędzy?}

Polska - zarówno jako przestrzeń w rozumieniu fizycznym, jak i ta fantazmatyczna - znajduje się wystarczająco daleko, aby wyraźną linią oddzielić doświadczenie życia w Izraelu od doświadczenia żydowskiej krzywdy, czyniąc Izrael miejscem wolnym od cierpienia, a zarazem jej fantazmat jest wystarczająco silnie zakorzeniony w zbiorowym myśleniu, aby stworzyć stabilną symboliczną przestrzeń, długotrwale przechowującą to doświadczenie, nawet w wypadkach, w których jego części składowe wiążą się w istocie z innymi obszarami geograficznymi i narodowymi (na przykład Niemcami, Czechami, Ukrainą, Litwą itd.). Przypominając o ciągle aktualnym zagrożeniu, pozwala też nadać mu jednoznacznie zewnętrzny charakter. Jednocześnie tworzony przez tę dychotomię dystans - przestrzenny i symboliczny - kazałby zadać pytanie o to, co znajduje się pomiędzy. Pomiędzy krajem śmierci a krajem życia, słabością a siłą, całkowitą biernością a bezwarunkową siłą i kontrolą, pomiędzy żałobą a euforią. Między Zagładą a odrodzeniem.

Brak jednoznacznej odpowiedzi na to pytanie w którymkolwiek z przytoczonych tekstów sygnalizuje schematyczność dychotomii, jej fantazmatyczną naturę. Podobną zależność charakteryzuje obrazująca postulat przedwojennego syjonizmu formuła „Mi-Tanach le-Palmach” („Od Pięcioksięgu do Palmachu”), pomijająca cały okres diaspory na drodze do odbudowania historycznej

${ }^{25}$ Ch. Nawe: Nos'im..., s. 259. 
ojczyzny. W tym wypadku pozostawione celowo i świadomie, oddzielone wyraźnymi granicami luki wynikają $\mathrm{z}$ mechanizmu określonego przez Amnona Raza-Krakotzkina mianem „Szelilat ha-galut” - odrzucenia diaspory, stanowiącego jeden $\mathrm{z}$ fundamentalnych postulatów syjonizmu na każdym etapie jego rozwoju ${ }^{26}$. Podobnie jak ten podział także opozycja między Polską a Izraelem, pozostawiająca wiele niewypełnionych przestrzeni pomiędzy, w tym wydaniu okazuje się sztuczna. Obydwa sformułowania budują bowiem konstrukcję mityczną opartą na podziale między odległą (czasowo i/lub przestrzennie) przestrzenią założycielską, punktem zero, od którego rozpoczyna się pisanie narodowej historii (starożytny Izrael, Polska), a żydowskim państwem jako tej historii nieodłącznym elemencie.

Tak skrojona opowieść, nie wzbudzając bardziej złożonych obaw, pozwala skrócić łańcuch wydarzeń do niezbędnego i optymistycznego minimum. A jednak to, co sprawdza się na poziomie narodowej mitologii, zdaje się jednocześnie nie wytrzymywać konfrontacji z rzeczywistością - przede wszystkim z realną przestrzenią. Podejmowana niekiedy $\mathrm{w}$ wyniku fizycznego zderzenia $\mathrm{z}$ polską przestrzenią próba odpowiedzi na stawiane już wcześniej pytanie o to, co „pomiędzy", kończy się fiaskiem. Być może właśnie dlatego Dana Szuchmacher, poetka trzeciego pokolenia, jeden $\mathrm{z}$ opisujących jej uczestnictwo w pielgrzymce wierszy kończy słowami: „[...] pomiędzy byłam pijana”"27.

\section{Bibliografia}

Ben-Amos A., Hoffman T.: Banu leszachrer et Majdanek. Masa'ot Cahal le-Polin we-gijus zikaron ha-Szo'a. "Israeli Sociology" 2011, Vol. 2, s. 331-354.

Chaitin J., Litvack-Hirsch T.: The Shoah Runs Through Our Veins. The Relevance of the Holocaust for Jewish-Israeli Young Adults. "Idea" 2015, Vol. 14, no 1. Dostępne w Internecie: http://www.ideajournal.com/articles.php?id=49 [data dostępu: 20.04.2018].

Feldman J.: Above The Death Pits, Beneath the Flag. Youth Voyages to Poland and the Performance of Israeli National Identity. New York 2008.

Grossman D.: Patrz pod: Miłość. Przeł. M. Sommer. Warszawa 2008.

Keret E.: Tęskniąc za Kissingerem. Przeł. A. Maciejowska. Warszawa 2008.

Modan R.: Ha-Neches. Tel Awiw 2013.

Modan R.: Zaduszki. Przeł. Z. Solakiewicz. Warszawa 2013.

${ }^{26}$ Por. A. Raz-Krakotzkin: Galut be-toch ribbonut. Le-bikoret „szelilat ha-galut” be-tarbut ha-israelit. Chelek szeni. „Tarbut u-wikoret”, Staw 1994, nr 5, s. 113-132.

${ }^{27}$ D. Szuchmacher: Sogrim Kajic. W: TAż: Czips we-keczop be-Zakopane. Jeruszalajim 2012, s. 43 . 
Nawe Ch.: Nos'im we-nos'ot. Sipurej masa ba-sifrut ha-iwrit he-chadasza. Jeruszalajim 2002.

Nir J.: Ha-Tkufa ha-kchula. Tel Awiw 2001.

Raz-Krakotzkin A.: Galut be-toch ribbonut. Le-bikoret „szelilat ha-galut” be-tarbut ha-israelit. Chelek szeni. „Tarbut u-wikoret”, Staw 1994, nr 5, s. 113-132.

SARID I.: Miflecet ha-zikaron. Tel Awiw 2017.

Szatran I.: Hiclachnu lefaceach et ha-Szo'a: Regew horta lehosif kolot rakewet we-newichot le-tekes ha-mesu'ot. Dostępne w Internecie: https://www.haaretz.co.il/ news/politi/1.6009376 [data dostępu: 17.04.2018].

Szuchmacher D.: Czips we-keczop be-Zakopane. Jeruszalajim 2012.

TAL-ON Z.: Lechacot et ha-okijanus. Lod 2015.

TOKAJER L.: Boker riszon be-Israel le-achar ha-mas'a le-Polin. W: Dor le-dor jawi'a omer lizkor we-lo liszkoach. Red. E. HaRtman. Aszkelon 2005, s. 395-396.

Tokajer L.: Lihijot be-Polin. W: Dor le-dor jawi'a omer lizkor we-lo liszkoach. Red. E. Hartman. Aszkelon 2005, s. 390.

Zertal I.: Naród i śmierć. Zagłada $w$ dyskursie i polityce Izraela. Przeł. J.M. KŁoczowSKI. Kraków 2010.

Jagoda Budzik

\author{
"Mi-Szoa li-tkuma” \\ Poland as an Antinomy of Israel
}

Summary

The aim of the article is to present and analyse texts whose authors - members of the Israeli Third Generation - refer in various ways to the phenomenon of pilgrimages to the memorial sites, attended by high school students for more than three decades. This phenomenon involves such questions as: the role of the Shoah in the Israeli collective narrative, the level of its institutional commemoration, relations between the act of memorialising the Holocaust and military activities, and lasting confidence in the experience of pilgrimage to Poland as part of the process of the Israeli youth's coming of age. The texts included in these reflections are used to portray the multiplicity of possible attitudes adopted by authors towards such methods of commemorating the Shoah - from unconditional acceptance, through the belief in their inevitability, to outright criticism.

Key words: Israeli memory of the Shoah, pilgrimages to Poland, Holocaust literature, Third Generation 